\title{
Ominous news for marine science
}

\author{
The Law of the Sea Conference is \\ over and the way in which marine \\ scientific research is to be organised \\ and controlled is not yet agreed.
}

Caracas - the site of the Third United Nations Conference on the Law of the Sea-a booming, noisy city, set amidst the green hills of the national park area. Ten weeks of slow and protracted discussions in three main committees, each open to delegates from all the 137 countries attending, plus numerous intergovernmental and nongovernmental bodies of all sizes, composition and pursuasion. Superb arrangements laid on by the Venezuelan Organising Committee, together with the United Nations Secretariat (at considerable cost) though a number of nations (particularly in Africa and Asia) expressed concern at the communication difficulties they have encountered and expressed their need to keep in close touch with their governments, particularly during the later negotiating stages of the conference. Chiefly for this reason it was decided to hold the next session in Europe.

Almost unanimous agreement that further sessions should not exceed six or seven weeks in length as humans get tired and stale if they attempt to confer for a longer period and little is achieved in the extra weeks. Winter troglodytes from northern latitudes trying to avoid another summer session -we have not had an opportunity to see our families in the sun for six years; smaller and less well off countries trying to reduce the length of future sessions, owing to the high cost of keeping large delegations abroadcountries have now had the opportunity to define their positions, let us get on with the negotiating and this will only happen during the final session; other countries talking about two sessions in 1975 and at least one in 1976.

Countries with differing views on the importance of the whole exercisesome suggesting that this was the most important conference that has ever taken place on the earth, and that we were trying to save civilization; others wondering whether the conference had the slightest relevance to the future of the human race; and still others believing sincerely that it was doing positive harm to the aspirations of the less developed countries.

Sharp disagreements within delega- tions, usually ending up with victory for military and economic interests over those of the marine scientists and environmentalists. Different types of disagreement between marine scientists - one faction claiming that freedom of scientific research in the oceans is essential for the future of scientific research as a whole, and that the restrictions proposed would either kill marine science dead or make it an undercover activity which no individual state or international authority could hope to prevent; or the opposing view-that developed countries have got to realise that the days of "Challenger' type expeditions at the expense of the natives are over, and it is now the turn of the developing countries.

These may be negotiating positions, of course, and doubtless if the declaration made by the President and endorsed by the conference on June 27 , is to have any effect, the extreme views will disappear in the interests of gaining concessions elsewhere. This declaration reads:

"Bearing in mind that the problems of ocean space are closely interrelated and need to be considered as a whole, and the desirability of adopting a Convention on the Law of the Sea which will secure the widest possible acceptance, the conference should make every effort to reach agreement on substantive matters by way of consensus and there should be no voting on such matters until all efforts at consensus have been exhausted."

This consideration is in fact vital when it is remembered that the first UN Conference on the Law of the Sea, Geneva, 1958, which produced four international conventions, has received relatively poor support from states. These were the Convention on the Territorial Sea and Contiguous Zone (46 states parties, in force since 1964); the Convention on the High Seas (54 states parties, in force since 1962); the Convention on Fishing and Conservation of the Living Resources of the High Seas (35 states parties, in force since 1966); the Convention on the Continental Shelf (53 states parties, in force since 1962). Furthermore, the second UN Conference on the Law of the Sea, Geneva, 1960, failed in its attempt to resolve disagreements over the breadth of the territorial sea and fishery limits.

The three main committees inherited the work of the UN Committee on the Peaceful Uses of the Sea-Bed and the Ocean Floor beyond the Limits of National Jurisdiction and it is on the lengthy deliberations of that committee over a period of five years that the present discussions are based and the texts of the convention articles will be developed.

It is becoming clear now that the final agreement will most likely include a territorial sea twelve miles in width, an economic zone beyond the territorial sea (referred to by the Latin Americans as the 'patrimonial sea') and an international zone covering the deep sea-bed, the water column being high seas. The general trend embodying several proposals is that countries where the width of the shelf is less than 200 miles, will have an economic zone of 200 miles covering both the shelf and the water column; others, where the shelf extends to over 200 miles, will have an economic zone of 200 miles and in addition sovereignty over the sea-bed out to the edge of the continental rise (this additional sovereignty will not include the water column). The fact that this limit is unidentifiable in most parts of the world because of the lack of data or lack of rise, has so far been conveniently ignored.

Among the more controversial matters on which as yet no agreement is in sight, are the extent of coastal state jurisdiction in the economic zone with regard to such matters as pollution control, scientific research, exploitation of living resources; and the degree of control to be exercised by the international authority over the international sea-bed area-this varies from the "none" of the states most physically capable of working in this area to the vesting of exclusive and direct control of all exploration and exploitation in the International Authority. A serious draft article "Right to undertake Marine Scientific Research", at present on the record, states "Marine scientific research in the international area shall be conducted directly by the international authority and, if appropriate, by persons, juridical or physical, through service contracts or associations or through any other such means as the International Authority may determine, which shall ensure its direct and effective control at all times over such research".

The fear of scientific research shown by many of the developing countries is based on two factors, one real and one controversial. The former is the military bogey, the possibility that a ship operating off the coast of another state may be gathering data inimical to the coastal state, in addition to its declared programme (and not necessarily oceanographic data; for example the 
Pueblo episode has been invoked on more than one occasion). In fact this is a case of the past behaviour of certain countries with regard to the release of oceanographic data coming home to roost. The theory behind the present World Data Centre system is that each country by injecting its data into the system qualifies to extract all data sent in by other countries. In fact a number of countries are notorious in that they participate in the system but, caught by military classification of data, they submit a minimum of their own, at the same time however calling loudly for complete submission of all data by others. This is particularly true of water temperature and to a lesser extent salinity data, of use to the military for acoustic detection of submarines. Marine pollution data, being of little military value, escapes the military clampdown.

The counter arguments deployed are that no convention or international regime is going to stop this type of behaviour. The navies of the world will continue with this policy until submarines or sonar become obsolete and it is the marine scientists wishing to work on other pressing problems who suffer.

The second fear is economic and is based on the premise that knowledge is power-in some unexplained way knowledge of the sea or sea-bed gained by a country carrying out scientific research, can be used to its economic advantage at the expense of the coastal state. In fact the coastal state desperately needs such knowledge if it is to benefit from any worthwhile exploitation of the area over which it has rights, and illegal exploitation which is a much slower process, will be far easier to prevent, particularly if the International Authority were developed to this end and the world's navies, which after all are the only possible forces that can police these areas, are mobilised in support.

At the present, the International Authority is seen by many countries as a panacea for all ills. There has been complete lack of consideration given to the way in which the authority will carry out its terms of reference and the structure it will need for this purpose, that is, how it will assess research projects submitted to it, whom it will recruit to carry out this task, what they will be looking for anyway. In theory, the authority will have to study each project submitted to it and to decide that the declared objective or purpose of the research is as stated, that it is not to the detriment of any coastal state (if in waters over which it has right) and that other criteria are laid down are being adhered to.

To undertake a task of this nature, a very large staff of highly qualified marine scientists of many disciplines would be needed and it is quite clear that inherent delays in obtaining consent would be enormous. At the same time that the developing countries are asking for the international authority to take on this vast and sophisticated task, they are clamouring for a transfer of technology, by which is meant an expanded training and education programme to build up their national marine science infrastructures. This latter exercise is fully justified but could well be killed by the former. But in any event very little detailed or serious consideration has been given to this subject and the conference has before it only one very general proposal dealing with the matter.

The basic world shortage of marine scientists in all but a few countries has

\section{"It is a sad reflection on our times that ... most delegations present consisted of lawyers and politicians, with little or no scientific support"}

led to a considerable reluctance by the United Nations and its specialised agencies to recruit top people in this field from the developing countries, as this usually results in an immediate weakening of the marine science infrastructures in the countries concerned; almost certainly these have been painstakingly built up over a number of years.

The staff, for a viable international authority capable of carrying out the assessment tasks proposed for it, would have to be obtained either from the very developed countries whose activities the authority has been set up to restrain or if, as is more likely, the United Nations staff quota system is used, largely from the developing countries; the latter arrangement would spell disaster to the marine aspirations of many of those countries.

There is also a real fear that the international authority will become yet another United Nations agency, to be paid for by the developed countries, that is, those countries whose activities will be most heavily constrained, with a complete lack of internal policy except to increase its empire and to become operational at the expense of other bodies which have been working in the same field, often for many years. Existing United Nations bodies already have a good if inadequate record of activity in this field; the Intergovernmental Oceanographic Commission of Unesco, for instance, already offers its member states an independent assessment facility for any project in which there is cause for dispute between a coastal state and a state wishing to carry out scientific research in waters over which the coastal state claims jurisdiction.

A fruitless exercise at present being carried out by certain of the developed countries, is an attempt to legislate separately for pure and applied research, as if these are rigidly definable activities. Certainly there is a white area of pure marine scientific research such as investigation of the history of the earth and the theory of plate tectonics; certainly there is a black area of applied research such as development of seismic survey methods to detect salt domes capping oil reservoirs, thus providing an indication to the oil companies of the most likely positions in which to drill to obtain a strike; but in between, there is a great grey area having both pure and applied connotations inextricably mixed, and anyway there is very little pure research that does not have an applied fallout of some kind. Besides this, such legislation would do considerable harm to applied research and survey work, needed by both developed and developing countries alike if the ocean resources are to be exploited economically for the benefit of mankind.

An unfortunate trend that has evolved during the Sea-bed Committee and conference sessions, has been the apparently successful attempt to lump all sorts of diverse data collecting activities under the heading of scientific research, which of course they are not and never have been; these include meteorological, oceanographic and bathymetric data gathering for such purposes as weather forecasting, compilation of navigational charts and so on. For instance, if a country wishes to place automated transmitting buoy systems (known as ocean data acquisition systems, aids and devices, or 'ODAS') off the coast to report the approach of hurricane force winds, this is now known as scientific research.

It is essential that such activities should be seen in their true perspective as ocean services-activities for the compilation of products for the benefit of developed and developing countries alike. Restrictions on data collection and exchange can help no one and do harm to many.

It is a sad reflection on our times that although, as pointed out by the Secretary of the Intergovernmental Oceanographic Commission to Commitee III, a basic knowledge of the oceans-what they are, how they behave, what they consist of, and so on -is essential to the success of the conference and the subsequent convention, yet most delegations present consisted of lawyers and politicians, with little or no scientific support. 